\title{
The diuretic effect of desmethyl-pipazuroyl-guanidine (MK-870) in man
}

\author{
The diuretic properties of desmethyl-pipazuroyl-guanidine (MK) have been investigated in \\ man and compared with hydrochlorothiazide (HC). In single-dose studies $M K$ (30 mg.) \\ had a slower onset of action and lower peak response than $H C$. It caused $K+$ retention and \\ did not affect $\mathrm{Cl}$ output. When administered daily for five days, $M K$ again had a lower peak \\ response than $H C$, but its effect was maintained for a longer period and after five days \\ the natriuresis produced by each drug was approximately the same. When $M K$ and $H C$ \\ were given together, there was a greater natriuresis and the $K$ loss produced by $\mathrm{HC}$ \\ was reduced. Both diuretics lowered blood pressure, but $M K$ appeared to be \\ less effective than $\mathrm{HC}$.
}

\author{
Gerharf Hitzenberger, M.D., Hermann Kampffmeyer, M.D., and \\ James Conway, M.D., Ph.D. Ann Arbor, Mich. \\ Departments of Internal Medicine and Pharmacology, University of Michigan Medical Center
}

A new drug, desmethyl-pipazuroyl-guanidine (MK), has shown promise in studies in animals ${ }^{1}$ and in $\operatorname{man}^{6,9}$ as a natriuretic agent with reduced excretion of potassium. The purpose of the present study was to assess the diuretic effect of $\mathrm{MK}$ in man and compare it with the effect of hydrochlorothiazide (HC); the two drugs in combination were also studied.<smiles>N=C(NC(=O)O)NC(=O)c1nc(Cl)c(N)cc1N</smiles>

Supported in part by Grants 5M01 FR-42-06, 5M01 FR-42-07, and 5T1 HE-5526-05 from the National Institutes of Health.

Received for publication May 1, 1967.
Our experimental design has been divided into three parts: (1) an acute study involving the administration of single doses of the drugs to normal subjects, (2) a six-day study in normal subjects, and (3) a seven-day balance study in hypertensive patients.

\section{Short-term study}

Methods. The study was carried out in 8 healthy young male volunteers who were admitted to the hospital for 36 hours. Prior to admission, they were given a "no added salt diet" and received supplementary sodium chloride $(3 \mathrm{Gm}$. per day) with a mean sodium intake of $180 \mathrm{mEq}$. per day. After midnight of the day of the experiment, no food or fluid intake was allowed; but during the next day, a standard sodium intake of $110 \mathrm{mEq}$. and a fluid intake of 
$200 \mathrm{ml}$. every 2 hours was given over a 14 hour period. No coffee, tea, or alcohol was given. At 8:00 A.M. the subjects received unidentified capsules of $\mathrm{MK}, \mathrm{HC}$, a combination of both, or a placebo. The order in which the subjects were given the drugs was determined by the Latin square method.

Between each of these studies, the sub- ject remained on the prescribed diet for one week. The subjects voided at 8:00 A.M. and thereafter every 2 hours for 16 hours and an overnight specimen from the sixteenth to twenty-fourth hours. Sodium, potassium, chloride, $\mathrm{pH}$, bicarbonate, titrable acidity, osmolality, and creatinine levels were determined in each urine sample. Uric acid output was de-

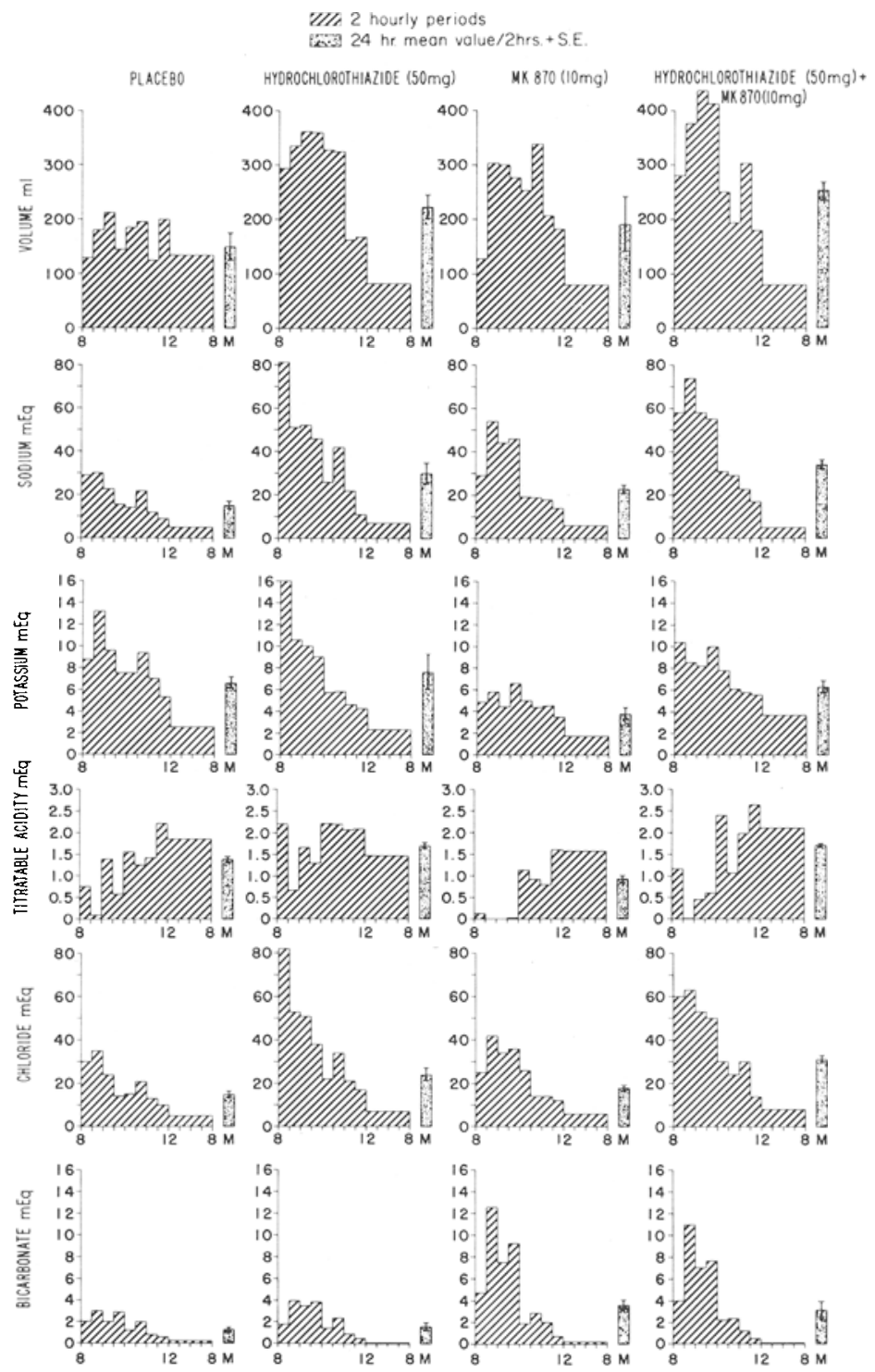

Fig. 1. Mean time course of the diuretic action of $M K$ and $H C$ alone and in combination as compared with placebo. Urine collections were made at two-hourly intervals from 8:00 A.M., when the drugs were administered, to midnight. The 24 hour output was then averaged to give the mean two-hourly output, indicated by $M$ on the time scale. 
termined for the whole 24 hour period. A single venous blood sample was drawn without venous stasis at 8:00 A.M. for sodium, potassium, chloride, bicarbonate, osmolality, and creatinine determinations.

Sodium and potassium were determined by flame photometry. Automated colorimetric methods were used for creatinine, chloride, and uric acid analyses. Osmolal concentrations were determined by the freezing point technique with the use of a Fiske osmometer. Titratable acid in urine was determined by titrating a small aliquot to $\mathrm{pH} 7.4$ with $0.10 \mathrm{~N}$ base, with a $\mathrm{pH}$ meter. Carbon dioxide content was measured on carefully protected urine and serum specimens with a Natelson microgasometer. These methods apply to all the parts of this report.

Two dosage levels of the drugs have been studied. Four subjects received $10 \mathrm{mg}$. MK (approximately $0.15 \mathrm{mg}$. per kilogram), $50 \mathrm{mg}$. HC, or two placebo capsules. The other 4 subjects received the same medications at double the above doses.

Results. Fig. 1 illustrates the time course and total effect of each drug regimen at the lower dosage as compared with placebo. In the doses given, $\mathrm{MK}$ had a slightly slower onset of action and both the peak natriuretic response and total effect were lower than for HC. The combination of the two drugs increased the output of sodium in 24 hours from 361 to
$407 \mathrm{mEq}$. Potassium excretion was significantly increased with $\mathrm{HC}$ and significantly reduced below control with MK (p $<0.05)$. In combination, the potassium excretion was approximately at the control level. The titratable acid was significantly reduced and $\mathrm{HCO}_{3}$ excretion was significantly increased with $\mathrm{MK}$, but chloride excretion was unaffected.

The osmolal clearance was not markedly enhanced with MK ( $4 \mathrm{ml}$. per minute compared to $3.7 \mathrm{ml}$. on the placebo day), whereas it was increased to $5.25 \mathrm{ml}$. per minute with $\mathrm{HC}$ and to $5.38 \mathrm{ml}$. per minute with the combination. The negative free water clearance of $-260 \mathrm{ml}$. per two-hour period on the placebo day was not significantly changed by the administration of MK (-266 ml.), but it was enhanced by $\mathrm{HC}$ ( $-340 \mathrm{ml}$.), and less pronounced by the combination $(-281 \mathrm{ml}$.). The uric acid output with $\mathrm{MK}$ was $677 \pm 97.4 \mathrm{mg}$. per day, while that with $\mathrm{HC}$ was $481 \pm 36.1$ mg. per day and the control was $558 \pm 57.0$ mg. per day. The combination of drugs gave an output very similar to $\mathrm{HC}, 488 \pm$ $78.1 \mathrm{mg}$. per day.

When the higher dose of the drug was used, the output of sodium was not significantly greater with $\mathrm{HC}$; with $\mathrm{MK}$, the output of sodium increased by only 53 $\mathrm{mEq}$. per 24 hours and this carried over to the combination of drugs (Table I). The potassium-conserving effect of MK was more prominent at the higher dosage

Table I. Mean (+ standard error) output per day

\begin{tabular}{|c|c|c|c|c|}
\hline \multicolumn{2}{|c|}{$\begin{array}{c}\text { Drug dose } \\
\text { (mg.) }\end{array}$} & $\begin{array}{l}\text { Sodium } \\
(m E q .) \\
\end{array}$ & $\begin{array}{l}\text { Potassium } \\
(m E q .)\end{array}$ & $\begin{array}{c}\text { Titratable acid } \\
(m E q .)\end{array}$ \\
\hline $\mathrm{HC}$ & $\begin{array}{r}50 \\
100\end{array}$ & $\begin{array}{l}360 \pm 36.1 \\
364 \pm 37.5\end{array}$ & $\begin{array}{r}91.0 \pm 22.3 \\
102.0 \pm 10.7\end{array}$ & $\begin{array}{l}20.0 \pm 2.4 \\
25.0 \pm 4.9\end{array}$ \\
\hline MK & $\begin{array}{l}10 \\
20\end{array}$ & $\begin{array}{l}271 \pm 24.1 \\
324 \pm 11.8\end{array}$ & $\begin{array}{l}46.0 \pm 8.8 \\
35.3 \pm 8.4\end{array}$ & $\begin{array}{l}11.0 \pm 2.3 \\
10.9 \pm 0.8\end{array}$ \\
\hline $\begin{array}{c}\text { Combinat } \\
\text { HC } \\
+\mathrm{MK}\end{array}$ & $\begin{array}{l}50 \\
10\end{array}$ & $408 \pm 28.0$ & $75 \pm 5.0$ & $20.6 \pm 1.6$ \\
\hline $\begin{array}{r}\mathrm{HC} \\
+\quad \mathrm{MK} \\
\end{array}$ & $\begin{array}{r}100 \\
20 \\
\end{array}$ & $476 \pm 20.6$ & $52 \pm 6.8$ & $10.8 \pm 8.7$ \\
\hline
\end{tabular}


Table II. Mean urinary values ( \pm S.E.) in 8 healthy male volunteers receiving MK-870

\begin{tabular}{|c|c|c|c|c|c|c|}
\hline & $\begin{array}{c}\text { Volume } \\
(\text { ml. })\end{array}$ & $\begin{array}{c}N a \\
(m E q .)\end{array}$ & $\begin{array}{c}K \\
(m E q .)\end{array}$ & $\begin{array}{c}C l \\
(m E q .)\end{array}$ & $\begin{array}{c}\text { Creatinine } \\
\text { clearance } \\
\text { (L./24 hours) }\end{array}$ & $\begin{array}{c}\text { Uric acid } \\
\text { clearance } \\
\text { (L. } / 24 \\
\text { hours })\end{array}$ \\
\hline $\begin{array}{c}\text { Without drug } \\
\text { (mean of } 4 \text { days) }\end{array}$ & $1,122 \pm 78.4$ & $191.7 \pm 12.2$ & $57.9 \pm 7.1$ & $148.5 \pm 19.7$ & $133.75 \pm 5.67$ & $12.08 \pm 0.59$ \\
\hline 1 day MK, $10 \mathrm{mg}$. & $1,373 \pm 143,9$ & $257.5 \pm 20.7$ & $43.1 \pm 2.4$ & $192.9 \pm 21.1$ & $136.75 \pm 14.34$ & $12.25 \pm 1.71$ \\
\hline 2 days $M K, 10 \mathrm{mg}$. & $1,378 \pm 119.5$ & $231.9 \pm 15.3$ & $46.6 \pm 5.1$ & $211.3 \pm 17.0$ & $133.57 \pm 10.77$ & $12.42 \pm 1.03$ \\
\hline 3 days $\mathrm{MK}, 10 \mathrm{mg}$. & $1,286 \pm 178.3$ & $138.8 \pm 17.1$ & $43.4 \pm 4.8$ & $172.9 \pm 20.5$ & $117.51 \pm 10.17$ & $13.29 \pm 3.23$ \\
\hline 4 days $\mathrm{MK}, 10 \mathrm{mg}$. & $1,326 \pm 188.5$ & $165.1 \pm 12.1$ & $62.7 \pm 6.9$ & $172.6 \pm 16.1$ & - & - \\
\hline 5 days $\mathrm{MK}, 20 \mathrm{mg}$. & $1,215 \pm 102.3$ & $165.1 \pm 19.8$ & $50.3 \pm 4.2$ & $160.0 \pm 21.1$ & - & - \\
\hline 6 days $\mathrm{MK}, 20 \mathrm{mg}$. & $1,366 \pm 194.8$ & $178.0 \pm 16.6$ & $56.1 \pm 3.8$ & $154.1 \pm 15.1$ & $134.2 \pm 6.12$ & $10.83 \pm 1.49$ \\
\hline
\end{tabular}

and this was maintained when the drugs were given together.

\section{Six day study in normal subjects}

Methods. This study was performed on an outpatient basis in 8 male subjects. Twenty-four hour urine collections were taken and measured for 4 days prior to treatment and for 6 days during treatment with MK. The volunteers ate a normal diet; only the intake of foods with high purine content was prohibited (liver, kidney). Tea and coffee were permitted, but in those who did it was mandatory that they take either two cups of coffee or tea per day. The subjects received MK, 5 mg. twice a day for 4 days, and then MK, $10 \mathrm{mg}$. twice a day for the remaining 2 days. A blood sample was drawn on three occasions before treatment and after the first, second, and fifth day of treatment for determination of sodium, potassium, chloride, $\mathrm{HCO}_{3}$, creatinine, uric acid, and hematocrit. In the urine, determinations of sodium, potassium, chloride, creatinine, and uric acid were made.

Three of these subjects undertook a further trial with $\mathrm{MK}$ at $30 \mathrm{mg}$. per day in divided dosage for 3 days to determine the blood levels of the drug. ${ }^{*}$ Venous blood samples were drawn, four after the first $10 \mathrm{mg}$. dose and then daily for 3 days.

* Determination of blood levels were performed for us by Merck Sharp \& Dohme through the courtesy of Dr. P. W. Boyles.
Results. The results of this study are presented in Table II. There was a modest increase in sodium output; the potassium excretion showed a slight drop for 3 days and returned to control levels on the fourth day. The increased dosage at this point had a small but temporary effect on the potassium output. The average uric acid level in the serum was $6.13 \mathrm{mg}$. per cent prior to the treatment and $6.04 \mathrm{mg}$. per cent after 5 days of treatment. Uric acid clearance did not change. There was a small drop in serum $\mathrm{HCO}_{3}$, with no substantial change in serum sodium, potassium, or chloride. There was no significant change in serum creatinine or in its excretion in the urine. A transient increase of the mean hematocrit level occurred after 2 days of treatment from 46 to 48 per cent.

The blood levels of MK increased from undectable levels to $0.02 \mathrm{mg}$. per milliliter within 4 hours of the administration of the first dose and then varied between 0.02 to $0.04 \mathrm{mg}$. per milliliter for the succeeding 3 days without evidence of progressive increase.

\section{Balance study in hypertensive patients}

Methods. These studies were carried out in the Clinical Research Unit of the University of Michigan Hospital on 15 untreated hypertensive patients. These patients were recruited from the outpatient clinic, and their disease states were of moderate severity with a mean blood pres- 
Table III. Mean diuretic response in five subjects to $M K(30 \mathrm{mg}$. per day) administered for 5 days followed by hydrochlorothiazide (100 mg. per day) for 2 days

\begin{tabular}{|c|c|c|c|c|c|c|c|c|c|c|}
\hline \multirow[b]{3}{*}{ Drug } & \multirow[b]{3}{*}{ Day } & \multirow{3}{*}{$\begin{array}{c}\text { Body } \\
\text { weight } \\
\text { (Kg.) }\end{array}$} & \multirow{2}{*}{\multicolumn{4}{|c|}{ Daily urinary output }} & \multicolumn{3}{|c|}{ Serum level } & \multirow{3}{*}{$\begin{array}{c}\text { Creatinine } \\
\text { clearance } \\
\text { (L. } / 24 \\
\text { hours })\end{array}$} \\
\hline & & & & & & & \multirow{2}{*}{$\begin{array}{c}N a \\
(m E q . / \\
L .)\end{array}$} & \multirow{2}{*}{$\begin{array}{c}K \\
(m E q . / \\
L .)\end{array}$} & \multirow{2}{*}{$\begin{array}{c}C l \\
(m E q . / \\
L .)\end{array}$} & \\
\hline & & & $\begin{array}{c}\text { Volume } \\
(\mathrm{ml} .)\end{array}$ & $\begin{array}{c}N a \\
(m E q .)\end{array}$ & $\begin{array}{c}K \\
(m E q .)\end{array}$ & $\begin{array}{c}C l \\
(m E q .)\end{array}$ & & & & \\
\hline Control & & $\begin{array}{c}68.7 \\
5.3 \uparrow\end{array}$ & $\begin{array}{r}1,114.0 \\
221.8 \uparrow\end{array}$ & $\begin{array}{c}28.4 \\
6.2 \dagger\end{array}$ & $\begin{array}{c}50.0 \\
4.1 f\end{array}$ & $\begin{array}{c}36.0 \\
8.5 \dagger\end{array}$ & $\begin{array}{r}143.8 \\
1.4 \dagger\end{array}$ & $\begin{array}{l}4.37 \\
0.16 \uparrow\end{array}$ & $\begin{array}{r}105.4 \\
0.97\end{array}$ & $\begin{array}{l}137.6 \\
12.6+\end{array}$ \\
\hline \multirow[t]{5}{*}{ MK } & 1 & $\begin{array}{r}68.3 \\
5.2\end{array}$ & $\begin{array}{r}1,647.0 \\
214.0\end{array}$ & $\begin{array}{r}162.8 \\
19.8\end{array}$ & $\begin{array}{r}43.8 \\
7.5\end{array}$ & $\begin{array}{r}79.0 \\
6.8\end{array}$ & $\begin{array}{r}142.6 \\
1.8\end{array}$ & $\begin{array}{l}5.15 \\
0.22\end{array}$ & $\begin{array}{r}106.8 \\
1.1\end{array}$ & $\begin{array}{r}136.4 \\
17.0\end{array}$ \\
\hline & 2 & $\begin{array}{r}67.7 \\
5.2\end{array}$ & $\begin{array}{r}1,703.0 \\
232.4\end{array}$ & $\begin{array}{r}166.0 \\
15.7\end{array}$ & $\begin{array}{r}53.2 \\
6.5\end{array}$ & $\begin{array}{r}130.0 \\
5.5\end{array}$ & $\begin{array}{r}142.2 \\
1.1\end{array}$ & $\begin{array}{l}4.88 \\
0.31\end{array}$ & $\begin{array}{r}107.2 \\
1.0\end{array}$ & $\begin{array}{r}119.2 \\
9.6\end{array}$ \\
\hline & 3 & $\begin{array}{r}67.5 \\
5.0\end{array}$ & $\begin{array}{r}1,787.0 \\
211.6\end{array}$ & $\begin{array}{r}149.9 \\
9.4\end{array}$ & $\begin{array}{r}64.2 \\
6.8\end{array}$ & $\begin{array}{r}138.0 \\
8.2\end{array}$ & $\begin{array}{r}141.5 \\
1.0\end{array}$ & $\begin{array}{l}4.79 \\
0.20\end{array}$ & $\begin{array}{r}106.2 \\
0.9\end{array}$ & $\begin{array}{r}127.0 \\
17.4\end{array}$ \\
\hline & 4 & $\begin{array}{r}67.6 \\
5.4\end{array}$ & $\begin{array}{r}1,439.0 \\
133.9\end{array}$ & $\begin{array}{r}112.2 \\
6.4\end{array}$ & $\begin{array}{l}66.5 \\
12.5\end{array}$ & $\begin{array}{r}107.0 \\
6.9\end{array}$ & $\begin{array}{r}142.2 \\
0.5\end{array}$ & $\begin{array}{l}5.21 \\
0.15\end{array}$ & $\begin{array}{r}106.4 \\
1.2\end{array}$ & $\begin{array}{r}119.2 \\
7.2\end{array}$ \\
\hline & 5 & $\begin{array}{r}67.3 \\
5.5\end{array}$ & $\begin{array}{r}1,825.0 \\
114.5\end{array}$ & $\begin{array}{r}107.0 \\
4.3\end{array}$ & $\begin{array}{l}67.3 \\
20.1\end{array}$ & $\begin{array}{r}130.0 \\
1.0\end{array}$ & $\begin{array}{r}141.2 \\
0.9\end{array}$ & $\begin{array}{l}5.13 \\
0.32\end{array}$ & $\begin{array}{r}106.8 \\
1.1\end{array}$ & $\begin{array}{r}123.2 \\
18.7\end{array}$ \\
\hline \multirow[t]{2}{*}{$\mathrm{HC}$} & 1 & $\begin{array}{r}66.9 \\
5.4\end{array}$ & $\begin{array}{r}1,886.0 \\
327.2\end{array}$ & $\begin{array}{r}132.8 \\
21.2\end{array}$ & $\begin{array}{r}134.2 \\
3.4\end{array}$ & $\begin{array}{r}182.0 \\
32.4\end{array}$ & $\begin{array}{r}141.0 \\
1.3\end{array}$ & $\begin{array}{l}5.02 \\
0.30\end{array}$ & $\begin{array}{r}103.0 \\
1.6\end{array}$ & $\begin{array}{r}101.4 \\
33.0\end{array}$ \\
\hline & 2 & $\begin{array}{r}66.7 \\
5.4\end{array}$ & $\begin{array}{r}1,322.0 \\
157.6\end{array}$ & $\begin{array}{l}78.2 \\
19.1\end{array}$ & $\begin{array}{r}112.8 \\
5.2\end{array}$ & $\begin{array}{r}129.0 \\
12.7\end{array}$ & $\begin{array}{r}140.4 \\
0.2\end{array}$ & $\begin{array}{l}3.96 \\
0.17\end{array}$ & $\begin{array}{r}101.0 \\
1.5\end{array}$ & $\begin{array}{r}118.6 \\
13.1\end{array}$ \\
\hline
\end{tabular}

*Control represents the mean of the values for 2 days preceding the administration of the diuretic.

$\uparrow$ Standard error.

sure of 169/107 mm. Hg. None had papilledema or hemorrhages and exudates. The subjects had normal renal function and no evidence of cardiac failure; clinical edema was not evident in any subject. They were given a $44 \mathrm{mEq}$. sodium diet with supplementation to $94.8 \mathrm{mEq}$. per day. There was no fluid restriction. Body weight was recorded daily and a determination was made of serum sodium, potassium, chloride, bicarbonate, uric acid, and creatinine. The urine was collected every 24 hours for determination of volume, sodium, potassium, chloride, creatinine, and uric acid.

After a control period of 4 days, the 15 subjects were divided into 3 groups of 5 each. Group A was treated with MK, 30 mg. per day for 5 days, which was then discontinued and immediately changed to $\mathrm{HC}, 100 \mathrm{mg}$. per day for 2 days. In Group $\mathrm{B}$, the effect of HC, $100 \mathrm{mg}$. per day, was studied. After 5 days MK, $30 \mathrm{mg}$. per day was added. In Group C, $50 \mathrm{mg}$. per day of $\mathrm{HC}$ was given, and after 5 days $30 \mathrm{mg}$. per day of MK was added.

\section{Results.}

Group A. The results of Group A are shown in Table III. A rise in urine volume was observed and maintained for the 5 days of treatment with MK. The body weight showed a moderate but steady decrease of $1.4 \mathrm{Kg}$. and decreased further with the addition of $\mathrm{HC}$. The sodium output increased with $\mathrm{MK}$, being greatest on the first day of the drug administration (162.8 $\mathrm{mEq}$. per day) and falling to 107.0 $\mathrm{mEq}$. per day in 5 days. The change to HC treatment at this point increased the output to $132.8 \mathrm{mEq}$. per day, demonstrating $\mathrm{HC}$ to be a more potent diuretic in the dosage used.

The creatinine clearance was reduced by 14.4 L. per day with administration of MK and was further reduced with HC. A 
Table IV. Mean diuretic response in 5 subjects to hydrochlorothiazide (100 mg. per day) administered for 5 days followed by hydrochlorothiazide (100 mg. per day) and MK (30 mg. per day) combined

\begin{tabular}{|c|c|c|c|c|c|c|c|c|c|c|}
\hline \multirow[b]{3}{*}{ Drug } & \multirow[b]{3}{*}{ Day } & \multirow{3}{*}{$\begin{array}{c}\text { Body } \\
\text { weight } \\
\text { (Kg.) } \\
\end{array}$} & \multirow{2}{*}{\multicolumn{4}{|c|}{ Daily urinary output }} & \multicolumn{3}{|c|}{ Serum level } & \multirow{3}{*}{$\begin{array}{c}\text { Creatinine } \\
\text { clearance } \\
(\text { L. } / 24 \\
\text { hours })\end{array}$} \\
\hline & & & & & & & \multirow{2}{*}{$\begin{array}{c}N a \\
(m E q . / \\
L .)\end{array}$} & \multirow{2}{*}{$\begin{array}{c}K \\
(m E q . / \\
L .)\end{array}$} & \multirow{2}{*}{$\begin{array}{c}C l \\
(m E q . / \\
L .)\end{array}$} & \\
\hline & & & $\begin{array}{c}\begin{array}{c}\text { Volume } \\
(\mathrm{ml} .)\end{array} \\
\end{array}$ & $\begin{array}{c}N a \\
(m E q .)\end{array}$ & $\begin{array}{c}K \\
(m E q .) \\
\end{array}$ & $\begin{array}{c}C l \\
(m E q .) \\
\end{array}$ & & & & \\
\hline \multicolumn{2}{|l|}{ Control $^{*}$} & $\begin{array}{c}76.4 \\
3.2 \uparrow\end{array}$ & $\begin{array}{c}1,561.1 \\
230.5 \dagger\end{array}$ & $\begin{array}{l}84.3 \\
13.8 \uparrow\end{array}$ & $\begin{array}{c}63.8 \\
5.37\end{array}$ & $\begin{array}{c}90.6 \\
9.4 \uparrow\end{array}$ & $\begin{array}{r}141.2 \\
0.6 \uparrow\end{array}$ & $\begin{array}{l}4.15 \\
0.197\end{array}$ & $\begin{array}{c}106.4 \\
1.1 f\end{array}$ & $\begin{array}{r}134.2 \\
5.2 \nmid\end{array}$ \\
\hline \multirow[t]{5}{*}{$\mathrm{HC}$} & 1 & $\begin{array}{r}75.1 \\
3.2\end{array}$ & $\begin{array}{r}2,875.0 \\
371.0\end{array}$ & $\begin{array}{r}267.8 \\
19.1\end{array}$ & $\begin{array}{r}114.4 \\
15.8\end{array}$ & $\begin{array}{r}289.4 \\
8.5\end{array}$ & $\begin{array}{r}139.8 \\
0.8\end{array}$ & $\begin{array}{l}3.72 \\
0.08\end{array}$ & $\begin{array}{r}101.8 \\
1.1\end{array}$ & $\begin{array}{r}151.8 \\
16.6\end{array}$ \\
\hline & 2 & $\begin{array}{r}74.7 \\
3.2\end{array}$ & $\begin{array}{r}2,013.0 \\
187.6\end{array}$ & $\begin{array}{r}146.0 \\
4.1\end{array}$ & $\begin{array}{r}86.8 \\
8.4\end{array}$ & $\begin{array}{r}167.2 \\
5.8\end{array}$ & $\begin{array}{r}140.0 \\
0.7\end{array}$ & $\begin{array}{l}4.01 \\
0.08\end{array}$ & $\begin{array}{r}99.2 \\
1.2\end{array}$ & $\begin{array}{r}120.6 \\
11.9\end{array}$ \\
\hline & 3 & $\begin{array}{r}74.3 \\
3.3\end{array}$ & $\begin{array}{r}1,828.0 \\
255.9\end{array}$ & $\begin{array}{r}97.2 \\
2.1\end{array}$ & $\begin{array}{l}98.2 \\
14.5\end{array}$ & $\begin{array}{r}119.4 \\
3.8\end{array}$ & $\begin{array}{r}140.8 \\
0.9\end{array}$ & $\begin{array}{l}3.65 \\
0.11\end{array}$ & $\begin{array}{r}99.2 \\
1.0\end{array}$ & $\begin{array}{r}127.0 \\
7.7\end{array}$ \\
\hline & 4 & $\begin{array}{r}74.1 \\
3.2\end{array}$ & $\begin{array}{r}1,774.1 \\
296.4\end{array}$ & $\begin{array}{r}81.6 \\
7.9\end{array}$ & $\begin{array}{r}100.2 \\
13.1\end{array}$ & $\begin{array}{r}97.8 \\
0.6\end{array}$ & $\begin{array}{r}140.0 \\
0.9\end{array}$ & $\begin{array}{l}3.57 \\
0.60\end{array}$ & $\begin{array}{r}99.4 \\
1.0\end{array}$ & $\begin{array}{r}126.6 \\
7.9\end{array}$ \\
\hline & 5 & $\begin{array}{r}73.9 \\
3.2\end{array}$ & $\begin{array}{r}1,626.0 \\
302.5\end{array}$ & $\begin{array}{r}70.0 \\
9.2\end{array}$ & $\begin{array}{l}94.8 \\
12.0\end{array}$ & $\begin{array}{r}83.8 \\
5.2\end{array}$ & $\begin{array}{r}138.2 \\
0.3\end{array}$ & $\begin{array}{l}3.35 \\
0.06\end{array}$ & $\begin{array}{r}98.4 \\
1.1\end{array}$ & $\begin{array}{r}124.4 \\
9.2\end{array}$ \\
\hline \multirow[t]{2}{*}{$\begin{array}{l}\mathrm{HC} \\
+\mathrm{MK}\end{array}$} & 1 & $\begin{array}{r}73.8 \\
3.2\end{array}$ & $\begin{array}{r}1,937.4 \\
210.5\end{array}$ & $\begin{array}{r}177.8 \\
15.9\end{array}$ & $\begin{array}{r}35.2 \\
8.8\end{array}$ & $\begin{array}{r}93.8 \\
7.6\end{array}$ & $\begin{array}{r}138.2 \\
0.5\end{array}$ & $\begin{array}{l}3.89 \\
0.12\end{array}$ & $\begin{array}{r}99.8 \\
0.8\end{array}$ & $\begin{array}{r}110.6 \\
7.4\end{array}$ \\
\hline & 2 & $\begin{array}{r}73.6 \\
3.2\end{array}$ & $\begin{array}{r}1,885.0 \\
210.5\end{array}$ & $\begin{array}{r}160.2 \\
11.3\end{array}$ & $\begin{array}{r}34.0 \\
7.1\end{array}$ & $\begin{array}{r}102.2 \\
12.4\end{array}$ & $\begin{array}{r}137.5 \\
1.0\end{array}$ & $\begin{array}{l}4.38 \\
0.17\end{array}$ & $\begin{array}{r}102.2 \\
1.1\end{array}$ & $\begin{array}{r}121.0 \\
6.0\end{array}$ \\
\hline
\end{tabular}

"Control represents the mean of the values for 2 days preceding the administration of the diuretic.

† Standard error.

small rise in uric acid excretion was found with MK. This averaged 661.28 $\pm 112.6 \mathrm{mg}$. per day, whereas the mean 24 hour excretion was $537.8 \pm 64.3 \mathrm{mg}$. per day prior to treatment. This difference was significant at the 5 per cent level. The mean serum uric acid value was, however, not altered.

The serum bicarbonate level fell from $28.7 \pm 2.0$ to $23.3 \pm 9.5 \mathrm{mEq}$, reflecting a slight metabolic acidosis; this was reversed with $\mathrm{HC}$ rising to $29.6 \pm 3.4 \mathrm{mEq}$. per liter. The mean blood pressure before therapy was $167 / 106 \mathrm{~mm}$. Hg; it fell to $152 / 103 \mathrm{~mm}$. $\mathrm{Hg}$ with $\mathrm{MK}$ and then to 135/92 mm. Hg with HC.

\section{Results.}

Group B. The results of Group B are shown in Table IV. When compared with the response to $\mathrm{MK}$, the sodium excretion was initially much greater with $\mathrm{HC}$. On the first day of treatment it reached a peak of $267.8 \mathrm{mEq}$. per day but it fell rapidly to $70 \mathrm{mEq}$. per day in 5 days; it rose when MK was added. Simultaneously, there was a fall in serum sodium concentration from 141.2 to $138.2 \mathrm{mEq}$. with $\mathrm{HC}$ and to 137.5 with the combination. The total negative sodium balance at this point was calculated to be $302.7 \mathrm{mEq}$. The potassium excretion increased markedly with $\mathrm{HC}$ and was sustained over the 5 day period of treatment, with a fall in the serum value from $4.1 \pm 0.35$ to $3.35 \pm 0.06$. With the addition of MK, potassium excretion was greatly reduced and the serum value returned to $4.38 \pm 0.17$ in 2 days.

The mean blood pressure in this section of the study fell from $172 / 110$ to $150 / 94$ with $\mathrm{HC}$ and to $134 / 90 \mathrm{~mm}$. $\mathrm{Hg}$ with the combination treatment of the two diuretics.

While HC was initially more potent than MK, its action was not sustained. When the 5 day periods during which 
Table V. Mean diuretic response in five hypertensive subjects to hydrochlorothiazide (50 $\mathrm{mg}$. per day) followed by hydrochlorothiazide (50 $\mathrm{mg}$. per day) and MK (30 mg. per day) combined

\begin{tabular}{|c|c|c|c|c|c|c|c|c|c|c|}
\hline \multirow[b]{3}{*}{ Drug } & \multirow[b]{3}{*}{ Day } & \multirow{3}{*}{$\begin{array}{c}\text { Body } \\
\text { weight } \\
\text { (Kg.) }\end{array}$} & \multirow{2}{*}{\multicolumn{4}{|c|}{ Daily urinary output }} & \multicolumn{3}{|c|}{ Serum level } & \multirow{3}{*}{$\begin{array}{c}\text { Creatinine } \\
\text { clearance } \\
\text { (L. } / 24 \\
\text { hours) }\end{array}$} \\
\hline & & & & & & & \multirow{2}{*}{$\begin{array}{c}N a \\
(m E q . / \\
L .)\end{array}$} & \multirow{2}{*}{$\begin{array}{c}K \\
(m E q . \\
L .\end{array}$} & \multirow{2}{*}{$\begin{array}{c}C l \\
(m E q . / \\
L .)\end{array}$} & \\
\hline & & & $\begin{array}{c}\text { Volume } \\
\text { (ml.) }\end{array}$ & $\mid \begin{array}{c}N a \\
(m E q .)\end{array}$ & $\begin{array}{c}K \\
(m E q .)\end{array}$ & $\begin{array}{c}C l \\
(m E q .)\end{array}$ & & & & \\
\hline \multirow{5}{*}{$\mathrm{HC}$} & & $\begin{array}{l}82.8 \\
3.15^{*}\end{array}$ & $\begin{array}{l}1,574 \\
\quad 93.70^{*}\end{array}$ & $\begin{array}{l}88.6 \\
6.64^{*}\end{array}$ & $\begin{array}{l}67.4 \\
3.95^{\text {* }}\end{array}$ & $\begin{array}{l}95.2 \\
14.56^{*}\end{array}$ & $\begin{array}{l}142.6 \\
1.87^{\text {* }}\end{array}$ & $\begin{array}{l}4.52 \\
0.28^{*}\end{array}$ & $\begin{array}{l}102.4 \\
1.10^{*}\end{array}$ & $\begin{array}{l}162.0 \\
13.36^{*}\end{array}$ \\
\hline & 1 & $\begin{array}{c}82.0 \\
2.97\end{array}$ & $\begin{array}{l}2,546 \\
259.60\end{array}$ & $\begin{array}{l}240.0 \\
17.06\end{array}$ & $\begin{array}{r}117.4 \\
9.59\end{array}$ & $\begin{array}{c}276.8 \\
23.36\end{array}$ & $\begin{array}{r}143.2 \\
3.81\end{array}$ & $\begin{array}{l}3.96 \\
0.21\end{array}$ & $\begin{array}{c}98.4 \\
1.89\end{array}$ & $\begin{array}{l}156.6 \\
17.52\end{array}$ \\
\hline & 2 & $\begin{array}{c}81.3 \\
2.86\end{array}$ & $\begin{array}{l}1,885 \\
463.0\end{array}$ & $\begin{array}{c}124.3 \\
22.11\end{array}$ & $\begin{array}{c}113.7 \\
20.96\end{array}$ & $\begin{array}{c}152.0 \\
26.12\end{array}$ & $\begin{array}{r}140.0 \\
0.63\end{array}$ & $\begin{array}{l}3.85 \\
0.21\end{array}$ & $\begin{array}{c}99.4 \\
0.89\end{array}$ & $\begin{array}{c}133.3 \\
13.10\end{array}$ \\
\hline & 3 & $\begin{array}{c}81.0 \\
2.78\end{array}$ & $\begin{array}{l}1,391 \\
133.36\end{array}$ & $\begin{array}{c}85.4 \\
3.91\end{array}$ & $\begin{array}{r}115.0 \\
10.7\end{array}$ & $\begin{array}{r}112.7 \\
4.63\end{array}$ & $\begin{array}{r}142.2 \\
1.31\end{array}$ & $\begin{array}{l}3.9 \\
0.25\end{array}$ & $\begin{array}{c}99.4 \\
1.67\end{array}$ & $\begin{array}{c}133.8 \\
8.10\end{array}$ \\
\hline & 4 & $\begin{array}{c}80.8 \\
2.90\end{array}$ & $\begin{array}{l}1,546 \\
191.50\end{array}$ & $\begin{array}{c}81.8 \\
5.09\end{array}$ & $\begin{array}{r}124.0 \\
17.5\end{array}$ & $\begin{array}{c}112.4 \\
9.27\end{array}$ & $\begin{array}{r}141.0 \\
2.50\end{array}$ & $\begin{array}{l}3.5 \\
0.1\end{array}$ & $\begin{array}{c}98.3 \\
1.73\end{array}$ & $\begin{array}{c}174.0 \\
21.67\end{array}$ \\
\hline \multirow{3}{*}{$\begin{array}{l}\mathrm{HC} \\
+\mathrm{MK}\end{array}$} & 5 & $\begin{array}{c}79.3 \\
2.92\end{array}$ & $\begin{array}{l}1,250 \\
169.93\end{array}$ & $\begin{array}{c}57.9 \\
5.69\end{array}$ & $\begin{array}{c}95.9 \\
1.66\end{array}$ & $\begin{array}{c}84.3 \\
6.69\end{array}$ & $\begin{array}{r}141.0 \\
0.61\end{array}$ & $\begin{array}{l}3.77 \\
0.16\end{array}$ & $\begin{array}{c}98.6 \\
1.30\end{array}$ & $\begin{array}{r}144.1 \\
6.60\end{array}$ \\
\hline & 1 & $\begin{array}{c}81.3 \\
3.12\end{array}$ & $\begin{array}{l}1,721 \\
247.57\end{array}$ & $\begin{array}{r}230.8 \\
6.21\end{array}$ & $\begin{array}{c}27.5 \\
5.64\end{array}$ & $\begin{array}{r}111.5 \\
3.78\end{array}$ & $\begin{array}{r}140.5 \\
0.56\end{array}$ & $\begin{array}{l}3.85 \\
0.2\end{array}$ & $\begin{array}{c}99.0 \\
1.64\end{array}$ & $\begin{array}{l}147.1 \\
12.34\end{array}$ \\
\hline & 2 & $\begin{array}{c}80.7 \\
3.08\end{array}$ & $\begin{array}{l}1,560 \\
198.0\end{array}$ & $\begin{array}{l}181 \\
10.24\end{array}$ & $\begin{array}{c}19.1 \\
3.27\end{array}$ & $\begin{array}{r}124.8 \\
5.45\end{array}$ & $\begin{array}{r}137.5 \\
0.75\end{array}$ & $\begin{array}{l}4.25 \\
0.14\end{array}$ & $\begin{array}{c}100.2 \\
1.46\end{array}$ & $\begin{array}{c}132.6 \\
18.47\end{array}$ \\
\hline
\end{tabular}

* Standard error.

each drug was given alone are compared, the total negative sodium balance with MK was $222.0 \mathrm{mEq}$. and $188.0 \mathrm{mEq}$. with $\mathrm{HC}$. Since the patterns of response to $\mathrm{MK}$ and $\mathrm{HC}$ were so different, it seemed desirable to determine whether this was a reflection of different pharmacologic properties of the two drugs or whether this was the result of differences in potency. A further trial was therefore, made with $\mathrm{HC}$ at lower dosage.

\section{Results}

Group C. With reduced dosage of $\mathrm{HC}$ (50 mg. per day), the peak response on the first day (240.0 mEq.) was a little lower than that achieved with the higher dose (Table V). On succeeding days, the response fell off sharply and on the third day was below the intake level $(85.4 \mathrm{mEq}$. per day). On the fifth day, the sodium balance was markedly positive; at this point the addition of MK ( $30 \mathrm{mg}$. per day) greatly increased sodium output.

\section{Discussion}

The sodium excretion with MK administration, in the doses used, when given as a single dose or for a single day never reached the peak values achieved by $\mathrm{HC}$. However, when the drug was given on successive days, the effectiveness of MK was better sustained; and over a 5 day period, the negative balance achieved was approximately the same as that with $\mathrm{HC}$ at the conventional maximal dosage of 100 mg. per day. There are several possible explanations for this. If there were a given quantity of sodium which could be readily removed, the weaker drug might continue 
to be effective until this was accomplished. This is not supported by the observations with $\mathrm{HC}$, in which reduction in dosage did not prolong response but shortened it.

Tissue levels of MK might increase on successive days. Others have found some evidence in 3 subjects for increasing blood concentration of MK, which could not be confirmed by us. MK may possess a dual action-a direct natriuretic effect and another and different one sustaining the natriuretic effect. This possibility is of interest since a response sustained over many days has also been observed with spironolactone. ${ }^{7}$ Thus, the continued availability of both potassium and chloride ions at the tubular exchange sites may assist the continued sodium output. Another possibility for the prolonged natriuretic effect is the production of a mild acidosis. This along with potassium retention will favor the movement of sodium from muscle cells into the extracellular fluid and make it available for excretion. ${ }^{3}$ It would be expected, therefore, that MK would result in an extraction of sodium from both the cellular and extracellular compartment, whereas $\mathrm{HC}$ would tend to bring about a loss of sodium from extracellular fluid with the possible accumulation of sodium in muscle cells.

$\mathrm{HC}$ and MK are for practical purposes, therefore, approximately equal in potency and in combination produce additive diuresis. Since it has been our feeling that the small size of the negative sodium balance achieved by HC limits its antihypertensive action, ${ }^{2}$ this combination may be of value in the treatment of hypertension. Furthermore, the added diuretic response may well be achieved without hypokalemia or alkalosis since the potassium retention achieved by MK can balance the loss from HC.

The potassium-saving effect was to be expected, from evidence in other studies. ${ }^{1,6,8,9}$ This effect is similar to that of triamterene ${ }^{5}$; but there is a less pronounced bicarbonate excretion and, therefore, a metabolic acidosis seems to occur more readily with MK than with triamterene. Thus, the effect of MK counteracting the metabolic hypokalemic alkalosis produced by HC seems to be more effective than that of triamterene. Since the single-dose studies showed that potassium output fell below control and in the longer studies serum potassium rose, it is misleading to use the term "potassium-sparing." Actually, there is potassium retention and hyperkalemia could occur. The accumulation of potassium in the doses used in this study appears to be limited to 2 to 3 days, however, and even when the drug is given on successive days, the output returns to control levels.

The decrease of the creatinine clearance which takes place with $\mathrm{MK}$ is similar to that with HC. This is not surprising since reduced renal blood flow and glomerular filtration rate have been reported with both ethacrynic acid and hydrochlorothiazide. ${ }^{4}$ This appears to be a response to the contraction in extracellular fluid volume and not the result of a specific effect of these drugs, since it is evident only after a considerable loss of sodium.

The effect of MK on uric acid excretion requires further study; it seems that a mild uricosuric action may have occurred after single doses as well as after a five day treatment. This could not, however, be demonstrated on a daily dose of 10 to $20 \mathrm{mg}$, MK over several days in outpatients.

At first glance MK seemed to be a mild diuretic with the virtue of conserving potassium. However, when given repeatedly over several days, its effect was better maintained than that of $\mathrm{HC}$. The negative sodium balance achieved is the same with both agents. When combined, a substantial natriuretic effect could be induced without hypokalemia. MK appeared to possess antihypertensive properties, as do other diuretic agents, and the combination with $\mathrm{HC}$ appeared to increase it. Since the effect of bed rest in these studies complicates the estimation of the antihypertensive effect, a different experimental design 
will be required to quantitate the antihypertensive action.

\section{Summary}

The diuretic action of desmethyl-pipazuroyl-guanidine (MK) has been investigated in 31 subjects and a comparison made with hydrochlorothiazide (HC). The drugs were also used in combination.

The results indicate that $10 \mathrm{mg}$. of $\mathrm{MK}$ was less potent a diuretic than $50 \mathrm{mg}$. of HC. These were approximately the maximally effective oral doses of these drugs in normal subjects. Both drugs had the same duration of action when given as a single dose. The output of potassium fell below control levels with MK, while bicarbonate excretion increased.

On continued therapy, MK (30 mg. per day) caused a smaller peak response than HC; but the natriuretic effect was sustained for at least 5 days as opposed to 3 days for $\mathrm{HC}$ ( $100 \mathrm{mg}$. per day), so that the negative sodium balance produced in 5 days by both was approximately equal. MK reduced the excretion of titratable acid and increased the excretion of bicarbonate, thus giving rise to a slight metabolic acidosis in contrast to the metabolic alkalosis produced by HC. The decrease in potassium excretion produced by this drug was limited to the first 2 to 3 days of therapy, after which it returned to the control level.

MK produced an added diuretic response to continued thiazide therapy and reversed the potassium loss and the slight alkalosis achieved with this drug. It also appeared to have an antihypertensive effect.
We wish to acknowledge the help of Dr. J. P. Chandler for the many laboratory analyses required for the study and Dr. W. Wilkinson of Merck Sharp \& Dohme for the supply of drugs and preclinical information concerning this agent.

\section{References}

1. Baer, J. E., Mucha, C. M., Spitzer, S. A., and Yee, H. W.: A $\mathrm{K}+$-sparing natriuretic pyraginamide derivation, Fed. Proc. 25:197, 1966.

2. Conway, J., and Leonetti, G.: Hypotensive effects of ethacrynic acid, Circulation 31:66I$664,1965$.

3. Cotlove, E., Holliday, M. A., Schwartz, R., and Wallace, W. M.: Effects of electrolyte depletion and acid-base disturbance on muscle cations, Am. J. Physiol. 167:655-675, 1951.

4. Dollery, C. T., Parry, E. H. O., and Young, D. S.: Diuretic and hypotensive properties of ethacrynic acid: A comparison with hydrochlorothiazide, Lancet 1:947-952, 1964.

5. Ginsberg, D. J., Saad, A., and Gabuzola, C. J.: Metabolic studies with the diuretic triamterene in patients with cirrhosis and ascites, New England J. Med. 271:1229-1235, 1964.

6. Gombos, E. A., Freis, E. D., and Moghadam, A.: Effect of MK-870 in normal subjects and hypertensive patients, New England J. Med. 275:1215-1220, 1966.

7. Hollander, W., Chobanian, M. C., and Williams, R. W.: Potential of the aldosterone antagonist in hypertension, Presented at the Symposium on the Clinical Use of Aldosterone Antagonists, Chicago, October 16, 1958, in Bartter, F. C., editor: Aldosterone antagonists, Springfield, Ill., 1960, Charles C Thomas, Publisher, pp. 169177.

8. Moukheibio, N. W., and Kirkendall, W. M.: Effect of amiprazinamide (MK-870) on electrolyte and water balance in patients with cirrhosis of the liver, Clin. Res. 13:425, 1965.

9. Singh, N. B., Richmond, D. E., Wilson, J. D., Simmonds, H. A., and North, J. D. K.: Evaluation of MK-870: A new potassium-sparing diuretic, Brit. M. J. 1:143-146, 1967. 